Quarterly

ISSN 1898-2255

Vol. 13, No. 2/2014

http://www.ekonomia.i.prawo.umk.pl
Article details:

Received: 11.06.2013

Revised: 30.10 .2014

Accepted: 03.11.2014

Bochenek M., Pomaskow J., The use of the brand to build a competitive advantage of contemporary companies, „Ekonomia i Prawo. Economics and Law.”, Polszakiewicz B., Boehlke J. (ed.), Vol. 13, No. 2/2014, pp. 285-296. DOI: http://dx.doi.org/10.12775/EiP.2014.021.

\author{
MirosłaW Bochenek*, Joanna PomaskoW**
}

\title{
THE USE OF THE BRAND TO BUILD \\ A COMPETITIVE ADVANTAGE OF CONTEMPORARY COMPANIES
}

\author{
SUMMARY
}

The aim of the article was to draw attention to the significance of one of the forms of non-price competition, which is creation of a strong brand. As the modern buyer pays more attention to branded products, the building and strengthening of global brands has become a primary objective of the companies that are in this respect almost forced to change their management style, striving for success in the international arena. Procter \& Gamble is aware of the fact that the brand has begun to gain importance in the competition on a global scale. The global brand has now become a guarantor of successful development of modern enterprises, and therefore it seems necessary to present solutions directly aimed at creating strong brands, which often require huge amounts of money on promotion and advertising.

Keywords: competition, brand, globalization

JEL Classification: M30, M31, M39

* Mirosław Bochenek, Nicolaus Copernicus University, Faculty of Economics Sciences and Management, Department of Economics, ul. Gagarina 13A, 87-100 Toruń, phone: +48 5661148 96, e-mail: bochenek@econ.uni.torun.pl. (corresponding author).

** Joanna Pomaskow, Nicolaus Copernicus University, Faculty of Economics Sciences and Management, Department of Economics, ul. Gagarina 13A, 87-100 Toruń, phone: +48 793613 002, e-mail: 227004@doktorant.umk.pl. 


\section{INTRODUCTION}

Until the end of the nineteenth century, companies conducted business in conditions similar to the model of free competition. The processes of concentration of capital and globalization of the world economy in the twentieth century led to changes in market structures. In most sectors there is monopolistic, also referred to as imperfect, competition. Monopolistic and oligopolistic companies do not conduct destructive price competition. The brand has become one of the most important instruments of competition. The authors of this study attempt to show how one of the leading companies in the market of household chemicals - Procter \& Gamble - uses the brand to increase its competitive advantage.

\section{THE GROWING IMPORTANCE OF THE BRAND IN THE ACTIVITIES OF BUSINESSES}

For most of today's corporations the main objective of operating a business is to create value for their shareholders ${ }^{1}$. The economic success of an organization depends also on its concern for environmental protection and community and staff development ${ }^{2}$. Companies wishing to build a competitive advantage and become market leaders must be characterized by flexibility of action and employ resources that are difficult to copy. Business organizations have come to believe that competitive advantages are to be found in other areas. Therefore, the ever-increasing importance of off-balance sheet intangible resources is observed, such as brand, image, customer loyalty, organizational culture, and human capital. In today's economic reality, the view that it is in the brand that new sources of business value should be sought, has gained general acceptance. Intangible resources are an important part of an organization's assets, which in turn are reflected in its market value. The growing importance of the brand stems also from its inclusion in a company's tangible assets, suitable for commercial use. These resources, to the extent they are exploited, are not subject to depreciation; what is more, they become enriched in the course of their use ${ }^{3}$.

${ }^{1}$ Cf. V. Jog, C. Suszyński, Zarzadzanie finansami przedsiębiorstwa, CIM, Warszawa 1994, p. 4.

2 Cf. A. Wheeler, Kreowanie marki, PWN, Warszawa 2010, p. 70.

${ }_{3}^{3}$ Cf. J. Szymczak, M. Urbaniak, Marka jako element jakości postrzeganej przez nabywców instytucjonalnych, [in:] Skrzypek E (ed.), Wptyw zasobów niematerialnych na wartośc firmy, Vol. 2, UMCS, Lublin 2003, p. 412. 
The multitude and variety of products offered on the market, and therefore a still growing competition, set new challenges for today's businesses. The placing on the market of new products involves huge costs and high risks. Therefore, companies operating in the market are constantly seeking ways to enhance their emotional relationship with their customers so that the products they offer are irreplaceable to consumers ${ }^{4}$.

Initially, the brand played only the role of a specific information carrier which compensated for limited data on purchased goods. The history of assigning brands to products dates back to the dawn of history, but the methods and functions of marking goods and services with brands have evolved over the centuries. Product labelling has its origins in antiquity. Then, names to identify the manufacturer were put on ceramic products. Medieval guild organizations limited and controlled the volume of craftsmen's and merchants' production and introduced the obligation on manufacturers of labelling their products in order to identify low-grade products. These markings were used as binding standards of quality, which were particularly important in the sale of products outside the sphere of influence of the mother guilds 5 .

Increased industrialization and urbanization led to a departure from selfsufficient households and forced the development of the market which supplied the population. It was not until the events of the late nineteenth and early twentieth centuries which caused the issue to be given a higher importance. In particular, technological advances in transportation and communications made possible as well as facilitated the export and import of manufactured goods. Thanks to the use of new technologies it was possible to produce cheaper products which were characterized by consistent quality on a mass scale. Developments in the field of manufacturing of packaging contributed to the individual marking of products with a brand. Thanks to mass advertisement, produced consumer goods became known among consumers as well as identified with a manufacturer's brand ${ }^{6}$.

${ }^{4}$ Cf. P. Tkaczyk, Zakamarki marki, HELION, Gliwice 2011, p. 10.

${ }^{5}$ Cf. G.S. Low, R.A. Fullerton, Brands, Brand Management, and the Brand Manager System: A Critical-Historical Evaluation, „Journal of Marketing Management”, Vol. 31, No. 2/1994, p. 173-189.

${ }^{6}$ Cf. G. Urbanek, Zarzadzanie marka, PWE, Warszawa 2002, p. 20. 


\section{THE BRAND AS A COMPETITIVE TOOL}

Today, the brand plays an important role, both for consumers and producers. It helps the consumer to identify and buy a product on the market; it indicates the level of prices, and guarantees high quality, which in turn builds confidence in the product and provides satisfaction in possessing it. In the age of mass production and anonymity, the brand replaces a manufacturer's personal contact with the ultimate buyer. Winning the consumers' trust helps businesses to create a positive image, shape brand loyalty, conduct effective promotional activities, create a good atmosphere around the manufacturer and its products, obtain higher prices, increase sales, and achieve success in the market. Owing to these advantages, the brand has become a company asset that can be traded on the market?

Today's companies operate in the so-called era of personalization, which departs from the bulk product addressed to a mass consumer and a pre-established market segmentation in the direction of individual segmentation. It lays emphasis on the level of customization of the product, as well as communication and consumption, because the consumer has become the most important player in marketing activities. The concept of economies of scale is slowly ceasing to be related to today's economic reality. Today, manufacturers and distributors increasingly base their profits on a high product margin. Where a product is desired by many consumers, it becomes a mass good, but only on the level of sales, because on the level of communication with the customer it remains individualized. The most significant change that has taken place thanks to modern marketing is the sole act of communicating with customers, which has ceased to be exclusively one-sided ${ }^{8}$.

Undoubtedly, the development of information technology coupled with emotional marketing has expanded managers' opportunities for integration of the community in the process of building and enhancing the value of brands. In this manner, a new tool for interactive communication between the brand and an almost unlimited range of users, has made more efficient diversification of a product offer possible ${ }^{9}$.

The successful development of a company often depends on the manufacture of quality products, also those addressed to the global market. Glo-

${ }^{7}$ Cf. J. Sala, Marka i produkty markowe, „Marketing i Rynek”, No. 2/1995, p. 9; M. Kieżel, Wizerunek marki i jego znaczenie, „Marketing i Rynek”, No. 6/1999, p. 14-16 and M. Bartosik, Marka na rynkach zagranicznych, „Marketing w Praktyce”, No. 7/2001, p. 49-50.

${ }^{8}$ Cf. R. Szopa-Milde, Autentycznośc, gtupcze!, „Marketing w Praktyce”, No. 6/2009, p. 29.

${ }^{9}$ Cf. T. Ziółkowski, Marketing XXI w.: od konsumenta do spoteczności, [in:] W. Jankowski (ed.), Strategie marek 2010, „Harvard Business Review Polska” 2001, p. 35. 
balization offers more opportunities to sell high quality modern products ${ }^{10}$. However, the globalization of the brand requires a global strategy that does not mean standardization of the product, but adaptation to local needs, in accordance with the slogan "think globally, act locally". These activities should not distort the character of a brand. Brand management requires that an enterprise should be aware of its essence. Products aimed at the global market must be characterized by high quality and an attractive price. High quality results from functional properties, among other things: durability, reliability, and safety of use, and adaptation to the mental needs of buyers, such as social status. Global brands are therefore carriers of certain attributes of a technical or emotional character ${ }^{11}$.

Only products manufactured with modern technology and targeted to the global consumer achieve the status of a global brand. Developed and established stereotypes and archetypes also promote globalisation of the brand. The main elements of the brand taken into account in the process of globalization are: logotype (logo and graphic identity of the company), the brand name, physical characteristics, and the packaging of the product. A characteristic feature of global brands is a shorter time for creating them. In addition, the creation of a global brand requires such marketing activities from a company as will help it to take the best position in its segment in the global market, gain recognition, and continuously confirm its position. The ideal solution is to create one brand for one company producing one product. Measures aimed at the creation of a strong brand are supported by enormous financial resources on advertising and promotion. Therefore, grand globalization makes companies modify their management style, reduce the number of brands they offer, and focus on brands with the greatest global potential ${ }^{12}$.

Looking at the problem of the use of the brand to build a competitive advantage from the perspective of buyers, consumers are tired of chasing novelties, they need a product brand that guarantees a sense of security and stability to them. The almost unlimited amount of goods available on the market together with mass marketing have contributed to the creation of a consumer society. The consumer existing in this society is no longer driven by desire to buy or own material goods, it's more about experiencing new, previous-

10 Cf. A. Gwiazda, Globalna strategia produktu, „Marketing i Rynek”, No. 1/1998, p. 12-13.

${ }_{11}$ Cf. J. Altkorn, Determinanty globalizacji marek, „Marketing i Rynek”, No. 4/1997, p. 3-5.

${ }^{12}$ Cf. T. Domański, Globalization of brands - new challenges for marketing, [in:] J. Dad'o, J.W. Wiktor (ed.), Marketing and globalization. Papers of the third international marketing symposium, Cracow University of Economics - Matej Bel University, Cracow-Banskà Bystrica 2000, p. $69-75$. 
ly unknown sensations which are provided by the the brand itself. Consumers purchasing goods acquire their own identity together with the goods. Today, this identity is being built of perishable items, as the product life cycle has become shorter. Buyers will make the decision to purchase goods more consciously and look for brands of repute, in a way which is predictable, and is able to meet real desires ${ }^{13}$.

In the era of a new, internationalizing global economy, manufacturers of global brands work closely together. Alliances between companies are not only a recipe for success, but also a condition for survival on the market. In this way, companies cooperating with one another form networks of brands which become new marketing strategies ${ }^{14}$.

In addition to manufacturers' brands there are trademarks. They are used by trade organizations (distributors) that organize the production and sale of goods under their brand ${ }^{15}$. Yielding to pressure from large distributors, weaker producers become anonymous products suppliers. Trademarks are a threat to small and weak producers ${ }^{16}$. Just like product brands, trademarks are also internationalized. But the process is much slower. Retail chains embark on expansion into culturally and geographically close markets ${ }^{17}$.

Promotion as an element of the marketing mix is an essential tool for building a strong and distinctive brand in the market. Through various forms of promotion, the company gains the ability to inform, encourage, and remind, directly or indirectly, potential buyers of its brands ${ }^{18}$. The promotion is designed to bring not only direct, quickly appearing profits, but also to build a strong image of the brand and the whole company, using the instruments at its disposal, such as: advertising, sales promotion, and public relations ${ }^{19}$. Advertising harmonizes perfectly with publicity activities. However, it should be just a reminder that it is extremely important, but only if the credibility of the brand is based on different marketing tools. Therefore, adver-

${ }^{13}$ Cf. R. Szopa-Milde, op. cit., p. 28 and M. Staniszewski, Zasobność marki, „Marketing w Praktyce", No. 6/2009, p. 37.

${ }^{14}$ Cf. S. Leitch, N. Richardson, Pajęczyna marek, „Marketing i Rynek”, No. 9/2004, p. 39-40.

${ }^{15}$ Cf. J. Sala, op. cit., p. 10.

${ }^{16}$ Cf. G. Urbanek, Zarzqdzanie markq w warunkach globalizacji, „Marketing i Rynek”, No. 10/2002, p. 14 and U. Kłosiewicz, Marki handlowe w Polsce, „Marketing i Rynek”, No. 6/2000, p. 29.

${ }^{17}$ Cf. C.M. Moore, J. Fernie, S. Burt, Marki handlowe bez granic, „Marketing i Rynek”, No. 1/2001, p. 36-37.

${ }^{18}$ Cf. M.K. Witek-Hajduk, Zrzqdzanie silnq markq, Oficyna a Wolters Kluwer business, Warszawa 2011, p. 157.

${ }^{19}$ Cf. K. Pawlak-Kołodziejska, Komunikacja marketingowa, [in:] K. Andruszkiewicz (ed.), Marketing. Podręcznik akademicki, TNOiK, Toruń 2011, p. 316-317. 
tising, while ceasing to be a tool to build a brand, gets the role of an instrument to support the power of the brand, after the earlier building of a solid foundation with the participation of public relations. Also, sales promotion plays a vital role in creating a brand because with its involvement, business organizations, through the use of a variety of economic and psychological incentives, are able to induce a rapid response by the buyers ${ }^{20}$. The increasing wealth of societies, individualization of consumption, and demand for branded products, as well as the increase in the concentration of production and increase in competition, predict increased importance and a good future of the brand. This is confirmed by the phenomena observed in developed countries where the share of these goods in retail is growing steadily ${ }^{21}$.

\section{THE EMERGENCE AND DEVELOPMENT OF PROCTER \& GAMBLE}

In its long, almost 200 year history Procter \& Gamble has repeatedly shown the strength to survive and thrive in the changing economic reality. The origins of the company date back to 1837 when the American manufacturer of candles, William Procter, entered into cooperation with his brotherin-law James Gamble, the owner of a company specializing in the manufacture of soap. As a result of the merger of two organisms, the partners founded a small factory in Cincinnati, Ohio, with an initial capital of $\$ 7,000^{22}$.

The company tuned its business to meet the needs of the contemporary market, taking advantage of the then modern technology. In 1931, Procter $\&$ Gamble was the first in its organizational structure to create a hitherto unknown managerial position dealing with issues of the brand, which in later years was successfully implemented by competitive companies ${ }^{23}$. Two years later, the company began to advertise brands of its products, especially soaps, in the intervals between the broadcasting of a popular radio series. Since then, radio series, and then television series, were commonly called soap operas ${ }^{24}$. From the very inception of the company, its founders embarked on the build-

${ }^{20} \mathrm{Cf}$. Ph. Kotler, Marketing. Analiza, planowanie, wdrażanie i kontrola, Felberg, Warszawa 1999, p. 609-619.

${ }^{21}$ Cf. J. Sala, op. cit., p. 10 and S. Segal-Horn, Firmy globalne - bohaterowie czy czarne charaktery?, „Marketing i Rynek”, No. 11/2002, p. 33.

${ }^{22}$ Cf. Pg.com, Poznaj globalnq historie PE'G, http://www.pg.com/pl_PL/firma/historia_globalna.shtml (01.05.2013).

${ }^{23}$ Cf. G. Urbanek, Zarzqdzanie markq, op. cit., p. 20.

${ }^{24}$ Cf. Pg.com, op. cit. 
ing of strong and recognized brands, realizing that such strategy would ensure the achievement of long-term competitive advantage.

Owing to its expansion into new geographic markets, Procter \& Gamble has become one of the largest and fastest-growing global companies. A1ready in 1997, it had 40 categories of products sold in 140 countries around the world; it also had 60 factories located throughout the world. At that time, $\mathrm{P} \& \mathrm{G}$ was also in the circle of the ten largest companies in the United States and the thirty largest companies in the world, employing some 100,000 employees and allocating about $\$ 1$ thousand million annually to research and product development ${ }^{25}$.

Employment at Procter \& Gamble has gradually increased, in May 2013, it counted more than 126,000 workers, living in 80 countries around the world. In addition, the concern owns as many as 25 brands with annual sales of a thousand million dollars each. Products offered by P\&G are available in more than 180 countries around the globe. Procter \& Gamble is not only one of the largest global concerns offering fast moving goods, used by hundreds of millions of loyal customers, it is primarily a mission to raise the daily quality of life for consumers around the world by providing them with branded products and services characterized by the best quality to price ratio. Since the beginning of its business, $P \& G$ has sought to be a leader or a vice-leader in each category, and therefore, has adopted the strategy of focusing on creating strong global brands. The concern has created a very strong product portfolio which consists of 50 brands, occupying the positions of the leader or vice-leader in their market categories. The recognition and reputation of $P \& G$ brands has a measurable impact on the concern's financial sphere, because they guarantee a total of $90 \%$ of revenues and profits on the global scale ${ }^{26}$.

\section{MEASURES TO STRENGTHEN THE COMPANY'S COMPETITIVE POSITION}

Promotional activities play a crucial role in building strong and distinctive Procter \& Gamble brands on the market. To a large extent, the company uses this instrument to make the presentation of their products, gain a significant competitive advantage, and create corporate identity. However, it also largely focuses on the building of specific consumer-brand ties, while creating a positive image of the whole organization. Using the instrument of promo-

\footnotetext{
${ }^{25}$ Ibidem.

${ }^{26}$ Cf. Forbes.com., http://www.forbes.com/companies/procter-gamble (01.05.2013).
} 
tional measures, it focuses simultaneously on several essential promotion tools: advertising, public relations, and sales promotion, supported by intense activity in the social media. Being the undisputed leader in innovation, the $P \& G$ concern has achieved many successes, but also quite a few failures, which are treated almost as a precious gift which makes it possible to learn lessons for the future.

Engaging well-known and recognizable personalities from the world of the media in advertising broadcasts is an excellent marketing tool, able to provide independently unquestionable competitive advantage and above-average sales. Today, staffing ambassadorial positions with well-known media personalities is an increasingly popular marketing tool that is used by companies of the beauty industry for the building and maintaining of brand strength. Procter \& Gamble uses this solution also in Poland. Initially, the company entrusted the position of the Pantene Pro-V brand ambassador to the famous actress Alicja Bachleda-Curuś, and when advertising broadcasts with her participation did not produce the expected results, her place was taken by Marta $\dot{Z}$ muda-Trzebiatowska. The new face of the brand became a great excuse to refresh the image of the brand and the existing Pantene Pro-V product line, and caused a significant increase in sales ${ }^{27}$. The $P \& G$ concern, aware of the importance of creating a positive image of the brand in the process of building a competitive advantage, engages professional advertising agencies to minimize the amount of errors made in this regard.

Modern consumers are increasingly choosing to buy fast-moving goods on-line. According to experts, this is fostered by the economic crisis and looking for savings in time and money. Forecasts indicate that it is the e-commerce market that will mark a double-digit growth in 2013 thanks to offering much cheaper products compared to traditional sales ${ }^{28}$. Additionally, $P \& G$ managers are calling for changes in thinking about the fast moving brand goods in the network as digital communications are becoming a real part of the brand value, which is the basis for building a market-competitive advantage. In their view, FMCG sector companies should put their main emphasis on the value of the brand in the field of digital communication with the consumer ${ }^{29}$.

${ }^{27}$ Cf. Stanek A., Gwiazda w reklamie? To się optaca, http://www.biztok.pl/Gwiazda-w-reklamie-To-sie-oplaca-s7159/foto_11 (05.05.2013).

${ }^{28}$ Cf. Ekonomia.rp.pl, Polacy kupujq coraz więcej przez Internet, http://www.ekonomia.rp.pl/ artykul/995347.html (05.05.2013).

${ }^{29}$ Cf. Proto.pl, Dyrektor generalny PEंG: interakcja z konsumentem musi być kreatywna $i$ oparta na wartości, http://www.proto.pl/archiwum/info?itemId=122870\&rob=Dyrektor_ 
Procter \& Gamble top managers believe that the emotional bond that the company creates through a dialogue with the consumer is also extremely important. $P \& G$ 's management is aware that the buyers who take the decision to purchase certain goods solely on the basis of facts are in the minority, which means that the majority of consumers makes purchases exclusively on the basis of emotions. Therefore, the creation of positive brand - consumer emotions is an area of particular interest in the era of a permanent lack of time to make a purchase decision even over the internet ${ }^{30}$.

The concern also clearly likes the currently immensely popular social networking services, such as Facebook. All brands belonging to P\&G exhibit a high degree of marketing activity in social media. In this regard, the work of the concern is also improved by the newly established office whose work has been devoted to the development of social activity. To the key objectives of marketing since 2010, Procter \& Gamble has added the provision of a significant and visible presence of all the brands belonging to the group on Facebook, while ignoring the costs that may result from this type of project. Despite initial scepticism about the effectiveness of advertising in social media, the concern has definitely pursued this activity ${ }^{31}$.

According to estimates carried out as part of a study commissioned by Procter \& Gamble, the total number of users of Facebook has exceeded 5 thousand million, which constitutes a substantial number of potential $P \& G$ consumers. Thus, the activities of the concern seem to be quite justified and worthy of the incurred expenses. In turn, the micro blog service Twitter is seen as a tool of similar effectiveness to traditional television. According to the concern's representatives it is more useful for the emissions of short single or multiple messages, including only current information about brands or products, rather than to the long term activities in brand creation. The concern is aware that the level of personalization in social networking sites such as Facebook is at an early stage of development, but has a huge targeting potential. Experts from $P \& G$ have seen huge benefits of being a daily part of life a wide range of consumers. Thus, the use of social media in promotion is an important element in a long-term strategy of creating strong brands of the global giant ${ }^{32}$.

generalny_P_G:_interakcja_z_konsumentem_musi_byc_kreatywna_i_oparta_na_wartosci (05.05.2013).

${ }^{30}$ Cf. A. Dobosz, Pokochać markę z lojalnościq, „Marketing w Praktyce”, No. 7/2007, p. 43-46.

${ }^{31}$ Cf. Marketing.org.pl, Facebook narzędziem marketingowym PE $G$, http://marketing.org.p1/ index.php/go=2/act=9/w=1/aid=m4b980914bdb47 (06.05.2013).

${ }^{32}$ Ibidem. 
A consumer market which was still almost completely anonymous a few years ago has now opened to cooperation with companies, inviting them to a dialogue with one another, sharing their acquired knowledge and experience. Only trustworthy companies may use valuable customers' advice. In return, customers offer them invaluable feedback, loyalty, and affection, which directly translates into an increase in the brand value, and thus a competitive advantage in the market ${ }^{33}$.

\section{CONCLUSION}

In the globalizing economy producers face new and growing challenges from consumers. To strengthen their position in the market in the conditions of increased competition, companies should produce goods of high quality, best - brand products. Unfortunately, Polish companies do not manufacture too many branded products and, therefore, they should benefit from the experience of others. The global giant Procter \& Gamble turns out to be leader in this field; its sustainable competitive advantage strategy consists in the creating of strong and distinctive brands, which have their own identity and are capable of engaging in long-lasting consumer-brand relations. The strategy, however, does prevent it from systematic development of the whole P\&G brand. The company has a high degree of absorption of innovation compared to its direct rivals, due to implementing new solutions based on specialized scientific knowledge and the awareness of the changes in consumers' needs. Substantial capital investment in fixed assets, mainly in the brand, enable the company to occupy and maintain a strong position in a highly competitive market of household chemicals.

\section{BIBLIOGRAPHY}

Altkorn J., Determinanty globalizacji marek, „Marketing i Rynek”, No. 4/1997. Bartosik M., Marka na rynkach zagranicznych, „Marketing w Praktyce”, No. 7/2001. Dobosz A., Pokochać markę z lojalnościq, „Marketing w Praktyce”, No. 7/2007. Domański T., Globalization of brands - new challenges for marketing, [in:] Dad'o J., Wiktor J.W. (ed.), Marketing and globalization. Papers of the third international marketing symposium, Cracow University of Economics - Matej Bel University, Cracow-Banskà Bystrica 2000.

${ }^{33}$ Ibidem. 
Ekonomia.rp.pl, Polacy kupujq coraz więcej przez Internet, http://www.ekonomia.rp.pl/ artykul/995347.html (05.05.2013).

Forbes.com., http://www.forbes.com/companies/procter-gamble (01.05.2013).

Gwiazda A., Globalna strategia produktu, „Marketing i Rynek”, No. 1/1998.

Jog V., Suszyński C., Zarzqdzanie finansami przedsiębiorstwa, CIM, Warszawa 1994.

Kieżel M., Wizerunek marki i jego znaczenie, „Marketing i Rynek”, No. 6/1999.

Kłosiewicz U., Marki handlowe w Polsce, „Marketing i Rynek”, No. 6/2000.

Kotler Ph., Marketing. Analiza, planowanie, wdrażanie i kontrola, Felberg, Warszawa 1999.

Leitch S., Richardson N., Pajęczyna marek, „Marketing i Rynek”, No. 9/2004.

Low G.S., Fullerton R.A., Brands, Brand Management, and the Brand Manager System: A Critical-Historical Evaluation, "Journal of Marketing Management", Vol. 31, No. 2/1994, http://dx.doi.org/10.2307/3152192.

Marketing.org.pl, Facebook narzędziem marketingowym $P E^{G} G$, http://marketing.org.pl/ index.php/go=2/act=9/w=1/aid=m4b980914bdb47 (06.05.2013).

Moore C.M., Fernie J., Burt S., Marki handlowe bez granic, „Marketing i Rynek”, No. $1 / 2001$.

Pawlak-Kołodziejska K., Komunikacja marketingowa, [in:] Andruszkiewicz K. (ed.), Marketing. Podręcznik akademicki, TNOiK, Toruń 2011.

Pg.com, Poznaj globalnq historię PEGG, http://www.pg.com/pl_PL/firma/historia_globalna.shtml (01.05.2013).

Proto.pl, Dyrektor generalny PËG: interakcja z konsumentem musi być kreatywna i oparta na wartosici, http://www.proto.pl/archiwum/info?itemId=122870\&rob=Dyrektor_ generalny_P_G:_interakcja_z_konsumentem_musi_byc_kreatywna_i_oparta_na_ wartosci (05.05.2013).

Sala J., Marka i produkty markowe, „Marketing i Rynek”, No. 2/1995.

Segal-Horn S., Firmy globalne - bohaterowie czy czarne charaktery?, „Marketing i Rynek", No. 11/2002.

Stanek A., Gwiazda w reklamie? To sie optaca, http://www.biztok.pl/Gwiazda-w-reklamie-To-sie-oplaca-s7159/foto_11 (05.05.2013).

Staniszewski M., Zasobność marki, „Marketing w Praktyce”, No. 6/2009.

Szopa-Milde R., Autentycznośc, gtupcze!, „Marketing w Praktyce”, No. 6/2009.

Szymczak J., Urbaniak M., Marka jako element jakości postrzeganej przez nabywców instytucjonalnych, [in:] Skrzypek E (ed.), Wplyw zasobów niematerialnych na wartość firmy, Vol. 2, UMCS, Lublin 2003.

Tkaczyk P., Zakamarki marki, HELION, Gliwice 2011.

Urbanek G., Zarzadzanie markq w warunkach globalizacji, „Marketing i Rynek”, No. $10 / 2002$.

Urbanek G., Zarzqdzanie marka, PWE, Warszawa 2002.

Wheeler A., Kreowanie marki, PWN, Warszawa 2010.

Witek-Hajduk M.K., Zrzadzanie silnq markq, Oficyna a Wolters Kluwer business, Warszawa 2011.

Ziółkowski T., Marketing XXI w.: od konsumenta do spoteczności, [in:] Jankowski W. (ed.), Strategie marek 2010, „Harvard Business Review Polska” 2010. 